\title{
School bureaucracy, ethnography and culture: Conceptual obstacles to doing ethnography in schools
}

The object of this essay is to offer a reflection on the obstacles that block the ethnographic intent when we try to do ethnography in school institutions. These obstacles are presented conceptually with reference to three main axes that shape school as a bureaucratic reality: school as a hypertrophied medium of individualistic codifying, school as a universalist and instrumentalist device, and school as a device to restrict the cultural field. These ideas are illustrated by means of some empirical examples, the majority of which come from an ongoing investigation in Guovdageaidnu, in northern Norway.

Key words school ethnography, bureaucracy, theory and methodology of ethnography, individualism, Saami school

This essay offers a contrast between two ways of understanding and constructing social reality: the way provided by ethnographic practice and the way that derives from a type of bureaucratic institution, the school. These two ways are opposed in some of their basic properties. When I examine them, I will suggest that it is impossible to produce data that are adequate for ethnography if we look at reality through the eyes of school bureaucracy.

Ethnography has become increasingly popular among pedagogues and, in general, among school agents, due to its potential for capturing the concrete social life of institutions. But we anthropologists have frequently criticised the use that school agents have made of ethnography, considering this use to be merely nominal in many cases (cf. Ogbu 1981; Wolcott 1985; Díaz de Rada and Velasco 1996; Velasco and Díaz de Rada 1997). On the other hand, the politics of school research, guided by school experts, may tend to exclude ethnography from its grant programmes, insofar as ethnography, in its search for complexity, is opposed to the positivist ideal of 'scientific' simplification (cf. Shulman 2002; Feuer et al. 2002; Erickson and Gutierrez 2002). In this essay I will present some keys to comprehending why the bureaucratic understanding of social reality prevents school experts from valuing ethnography and why it may even block a genuine ethnographic research intention.

In particular, I will present three ideological axes that constitute school bureaucracy: (1) the school hypertrophy of individualistic codifying of reality, (2) the universalist and instrumentalist constitution of the school and (3) the school's tendency to restrict 
the cultural field. The ideological scheme that results from the coordination of these principles is:

(a) instrumentalist, because it works under the assumption that the school is an educational device, that is, an instrument, that can, to a great extent, be isolated from the concrete social conditions that produce it;

(b) individualist, because it believes that the only possible subject of school learning is the individual, extracted from his concrete contexts of social life; and

(c) universalist, because it assumes that, once the universe of action, generally a nationstate or a nation, is defined, both school procedures and curriculum content will be valid for each and every person in this universe.

In the eyes of school bureaucracy, ethnography is simply impracticable right from the very genesis of the empirical material. This means that the researcher can carry out the routines that apparently make up anthropological fieldwork, can live with and communicate with people for a long time, and can deploy a range of 'qualitative' techniques, without, however, producing data adequate for ethnographic analysis and writing (cf. Wolcott 1985, 1990, 1999).

\section{School, bureaucracy and ethnography}

Everyone who heard and read this text earlier ${ }^{1}$ agreed on a critical point that, because of its importance, deserves an initial reflection. Good readers of ethnography, my commentators indicated that this essay gives an excessively monolithic vision of the school as a bureaucratic institution. I agree with them. When I underline the ideological aspects of the school as bureaucracy, I am presenting the school as if the way it processes its daily realities corresponds to a design so successful that it could not cause any of the frictions, conflicts and, possibly, the failures, that school ethnography has been eloquently pointing out for decades. School ethnographers have been captivated by the unveiling of what the institution, more or less implicitly, does, beyond its officially declared purposes (Dreeben 1968). We have insisted that a merely formalist examination of the school is useless, unless we reveal the concrete processes of cultural production that flesh and blood agents carry out (Willis 1978, 1981), the socialisation processes among their subjects that are not always transparent (Varenne 1982), and the practices that contaminate and in a way dirty the hygienic order of their precincts (Everhart 1983; Díaz de Rada 1996). I will not insist on this here.

All of these sources of inspiration are ideal for understanding what good ethnography says about schools, but they should not lead us to ignore the effects that schools have on ethnographers and ethnography, which is what this contribution

1 The first version of this essay was presented at the Primera Reunión Cientifica Internacional sobre Etnografía y Educación (Talavera de la Reina, July 2004). I would like to thank Graciela Batallán and Silvana Campanini (Universidad Nacional de Buenos Aires) and Diana Milstein (Universidad Nacional de Comahue, Argentina), for their comments during the session. My colleagues at the UNED, Francisco Cruces, María García Alonso and Eugenia Ramírez Goicoechea also contributed with their criticism to improving the text. Nancy Konvalinka translated this text to English. 
is about. What properties and axes of school functioning should we pay attention to in order to shift our focus away from our own school ethnocentrism as researchers? What should we expect from schools when we try to record what their agents do and say without reducing this social life to formal designs? In my opinion, what we should expect is for them to behave like bureaucracies. Because even though it is true that schools are much more than bureaucracies, it is also true, as Elizabeth Eddy (1975) showed in detail, that schools are, fundamentally, bureaucracies. To ignore this would lead us to construct a much rougher and ineffective idealisation than if we reduced the school to its formal processes.

The school is a special educational institution. Built by modern national states in our historical environment, this institution is special because it introduces a regime of action that belongs to a planned bureaucracy into the ordinary educational processes based on communication between human beings. What I will call 'school' here, following the definition that Judith Hansen gave us in 1979, is 'institutionalized education in which learners learn vicariously, in roles and in environments defined as distinct from those in which the learning will eventually be applied' (Hansen 1979: 28). As Jean Lave has pointed out, the basic assumption of this kind of education is that knowledge is transferable, to the point of being independent of the concrete agents who will need to use it (Lave 1989). This knowledge gives content to school bureaucracy, which also shares a complex set of properties with all other bureaucratic institutions. Bureaucracy, school or otherwise, is a moral order in which the justification for human actions is based on the rational legitimacy of the ends (Weber 1984), on the supposed technoinstrumental efficacy of the procedures (cf. Habermas 1984, 1988), and on the functional ordering of people and their tasks (Mayntz 1985, 1987). Thus, any bureaucracy is, simultaneously, a moral order, an expert system of representative and procedural knowledge, and an organisation of concrete human beings.

This essay will examine some of the basic principles of the ideological ordering of school bureaucracy. With reference to ethnographic practice, these axes work as conceptual obstacles or biases that may prevent us from contemplating the institutions' concrete social life.

\section{The shape of the data. Two ethnographic experiences}

To give a quick picture of the kind of conceptual obstacles that I want to discuss here, I will refer to two relatively recent research experiences that do not have the school as their object of study.

In 1997, we initiated a collective investigation in the Department of Social Anthropology at the Universidad Nacional de Educación a Distancia (UNED) that sought to analyse the different meanings of 'trust' and 'risk', as they are put into practice in the social relations between the agents of a set of local bureaucratic institutions and their users. We chose a series of locations to compare: a bank office, a set of airport services, a newborn unit in a large hospital, an Office for Attention to Citizens, various councils for citizen participation in Madrid districts, and a rural town hall ${ }^{2}$ (Cruces

2 This research was carried out with the aid of the Consejeria de Educación y Cultura de la Comunidad de Madrid (Projects 05C/003/1996 and 06/0102/1997), under the direction of Prof. Honorio Velasco (UNED). In Spain, an Office for Attention to Citizens is an institution which gives public administrative information, and receives the claims related to public and private services. 
et al. 2002). We knew that, with all the necessary conditioning factors, it would be relatively simple to describe how the practices of the institutional workers, clearly situated in their offices and at their counters, were organised. What was going to be difficult was approaching the users: anonymous and relatively universal populations, faceless aggregates with the profile conferred upon them by the universalistic logic of each particular institution: account numbers for the bank, bodies and organs for the hospital, and so on. These are subjects that are cut out ahead of time, so amputated that they do not allow a holistic approach. We did our best. Apart from approaching the users in the cut-out context of each bureaucratic establishment whenever possible, we worked with other users of these systems in discussion groups, with the objective of collecting samples of collectively produced discourse. It was better than nothing. I handled the specific study of the Office for Attention to Citizens of the Autonomous Community of Madrid. A small set of metaphors used by the workers in this office to refer to the users can illustrate the problem: 'masses', 'currents', 'flows', 'there doesn't seem to be much noise today', 'today we'll be snowed under'. The bureaucratic institution produces its own users by means of two basic operations: it defines them to fit itself and it conceives of them as aggregates, ignoring their specific contexts of social relations. Once they are cut out by the institutional function, they appear as floating sets of anonymous people.

The second research experience is more recent. I am studying the problem of social belonging and its ethno-political translations in northern Norway, based in a town called Guovdageaidnu. ${ }^{3}$ The majority of the population identifies itself as 'Saami' and speaks Saami. The majority are also 'Norwegian' citizens and speak Norwegian, as a result of a colonisation process that goes back several centuries. Approximately a third of the people in Guovdageaidnu make their living totally or partially from reindeer herding, involving seasonal migration. One outstanding aspect of this economic mode is its social organisation (cf. Paine 1994, 2004). And one of my main purposes in the investigation of social belonging in this area is to study in detail the historical continuities and discontinuities of the social units that make their living from reindeer herding. These social units are, even today, extended family groups called siiddat, that unequivocally acknowledge themselves to be organisations of subjects who are co-owners of rights in a dense network of relations. In order to study the continuity of these organisations as such, I have quite valuable descriptive information from the year 1911 (cf. Keskitalo 1998: 427 ff.) and from the year 1956 (Steen 1956). In the registers of these years, reconstructed by researchers, each social unit appears explicitly, with the names of all its members and the kinship and marriage relations among them. In 1976, the Norwegian state enacted a new law to organise this economic activity (Landbruksdepartementet 1978). One of its clauses created a legal figure called the 'working unit' (driftsenhet) that assigned ownership and operation rights for the herd to an individual holder, an adult individual, using the rationale that the state would thus be better able to identify and manage the whole of this economic activity. Yearly, the Norwegian Association of Saami Reindeer Herders (Norgga Boazosápmelaččaid Riikasearvi) makes an Agreement with the state that offers subsidies and resources. Since these subsidies and resources are assigned to the holders of the new working units, a new system of individual working

3 This ongoing project has received support from the Foreign Department of the Norwegian Government (Utenriksdepartementet), the Wenner-Gren Foundation for Anthropological Research (Gr. 6898 and 7092), the Vice-Rectorate for Research of the UNED, and the Program of Mobility for Professors from the Spanish Ministry of Education, Culture and Sports (PR2003-0276). 
units has, in the last 30 years, superimposed itself upon the traditional siiddat system (Kalstad 1999; Joks 2001). One of the consequences of this process is that the register of data has changed. My data for 2004 look like a nominal list of individuals, usually males. With the invaluable help of other documents and local experts, I am managing to reconstruct this list as complex family organisations. Discussion groups do not help with this. This example shows how bureaucratic processing blurs the cultural definitions of the social subjects, making the social constellations that the individuals do, in fact, inhabit invisible or irrelevant.

Both experiences show some aspects of how bureaucrats develop their realities. Specifically, how they develop the aspect of social reality that is most important for the kind of cultural interpretation that ethnography can offer: the who of social life. I hold that the ways bureaucracies develop social reality are contrary, in this fundamental aspect, to the ways ethnography develops social reality. This is the nucleus of all the problems that I will now comment on, focusing on schools.

Since I will be talking about problems derived from the very genesis of bureaucratic social reality, that is, from how bureaucracies try to construct society, I wish to highlight that we are dealing with problems that affect the immediate presentation of institutions, their public expressions. Therefore, these are not problems that come up during the desk-work of research, but biases that shape our empirical impressions in the field, thus putting the very shape of the data at risk. I also wish to highlight the fact that these biases have very little to do with an ingenuous identification between bureaucracy and the power of concealment, and that very little can be done to overcome them from an ingenuously anti-bureaucratic perspective. As conceptual obstacles, these biases are, on the contrary, even more acute, if possible, the more transparently the bureaucracies function, that is, the more clearly they try to function according to their own logic, and, to a great extent, to the legitimate logic that we expect from them.

\section{Realities}

The bureaucratic production of reality is contrary to the ethnographic production of reality with respect to four fundamental dimensions of our research model.

\section{(a) Subject}

The bureaucratic production of reality is contrary to a social science that has a subject. This means that, as in the case that I mentioned of the social units that participate in the reindeer activity, when we do ethnography, we look for social subjects who are agents of socialisation practices, complex subjects who process culture, that is, communication and meaning. However, bureaucracies work with individualistic summaries, extreme reductions of the subject. ${ }^{4}$ This is reasonable because this is how bureaucracies - in

4 The concepts of subject and agent are not single entities (cf. Giddens 1984; Ricoeur 1990; Asad 1993). Besides, ethnography fluctuates between two moral images of the individual: on one hand, it cannot allow itself to ignore the specificity of each individual in its field as an anthropological concrete (cf. Rapport 2003); on the other hand, it cannot allow itself to ignore the fact that each individual in its field is specific precisely in his relational worlds, each individual is who she is as an individual-in-relation. 
their particular forms of cultural production - understand how to work with subjects: desubjectifying them, turning them into individuals. How else could they register them? How else could any of us who work in bureaucracies do it?

\section{(b) Relation}

The bureaucratic production of reality is contrary to a relational social science. We must realise, on this point, that the category that is opposed to 'individual', in ethnographic terms, is not 'collective'. Moreover, the individual himself, as a subject confined to a biological body (cf. Harris 1989), presents no problem whatsoever to the ethnographic production of reality, as the extensive and very rich research based on life stories shows. The problem comes from the individualistic ideology of bureaucracy, with its categorical opposite being the holistic ideology of ethnography (Dumont 1987; Díaz de Rada 2003). The opposite of individualism is not collectivism, but holism, that is, inquiry into social relations. The logic of ethnographic research seeks to pursue the practical and theoretic relations among and within human institutions. On the contrary, the bureaucratic production of reality seeks to fragment the institutional whole, and to cut out what fits its procedures.

\section{(c) Concrete}

The bureaucratic production of reality is also contrary to a social science of what is concrete, which is exactly what ethnography pursues. The specific rationality of bureaucracies consists of conceiving human organisations to be a set of abstract kinds of knowledge, functions and procedures. Thus, bureaucracies highlight, axiologically, the profiles of their expert systems, abstract systems of knowledge and action, designed with pretensions to universality; they downplay the profiles of their concrete institutions, the establishments, the places and access points where, in fact, flesh and blood subjects put the conventional systems of rules into play (Giddens 1987, 1990; Velasco et al. 2006).

\section{(d) Process}

Finally, the bureaucratic production of reality is contrary to a social science of processes. Bureaucratic rationality concedes immense value to research about and the evaluation of results, and this preference is not balanced by the interest awakened by the human processes that lead to these results. Ethnography, however, can manage to give the opposite emphasis: the attempt to understand the results with reference to some kind of subject, in a concrete process of social relation. As Michael Herzfeld indicated, bureaucracy is characterised by the 'suppression of time' (Herzfeld 1992: 162). Because of this ideological suppression, it is often our special task to reconstruct the processes, basing our reconstructions on scraps of enormously fragmented data.

In the framework of these tensions between the way bureaucracies produce reality and the way ethnography produces reality, we can understand the axes that 
constitute school bureaucracy and that can turn into conceptual obstacles for practising ethnography. First, the school as a hypertrophied means of individualistic codification; second, the school as a universalistic and instrumental device; third, the school as an effective device for restricting the cultural field.

\section{The school as a hypertrophied means of individualistic codification}

In his collection of essays on individualism, Louis Dumont traced the path of the institutions that, in our tradition, have raised the individual to the condition of subject of history (Dumont 1987). We might be surprised to see that the school is not part of this path. However, if we read this book together with Prof. Carlos Lerena's work Reprimir $y$ liberar (Lerena 1983), it will help us to understand, historically, that the modern school, with its sentimental education, is to the state administration of individuals what Christianity is to its moral creation, modern law to its legal constitution, liberal economy to its commercial formation and, finally, the nation to its political genesis.

Where school individualism reveals itself most strongly is precisely in the attempts that the school makes to neutralise it. An article by Annette Lareau and Wesley Shumar investigates 'The Problem of Individualism in Family-School Policies' (Lareau and Shumar 1996). They begin by pointing out the official words of the Panel of Objectives for National Education in the United States: the intention of increasing 'parent involvement and participation' in the school (1996: 24). Their empirical research shows, however, that the different social positions of the parents insofar as their school abilities, their occupational flexibility, their economic resources, and their social networks prevent this participative ideal from being put into practice. The school's production of reality blurs these real contexts of social relations. And so, in the authors' words:

These differences in social resources were generally invisible to the educators, who, using an individualist model, interpreted the parents' efforts to attend school functions as an index of their level of concern. (Lareau and Shumar 1996: 26; emphasis added)

The subject constructed in the schools is a de-socialised individual. And the more de-socialised these individuals are, the more the institution aspires to convince them that their social origin is irrelevant for reaching the kingdom of upward mobility.

School individualism shapes the expressions that the institution offers us about itself: individual files, psychometric individuals, classrooms with individuals facing the front, paying attention one by one to what the teacher's individual voice is dictating, etc. These are all amputated data, data that are ethnographically poor, because right from their origin they are based on a reduction of relational thought.

Ethnography's task consists, then, of overcoming this reiterated individualist codification of the practices, understanding this codification to be a real process of institutional politics. Some of the classic objects of social anthropology have been observed at the edges of work and industrial productive process. In the school sphere, 
we are also destined to deal, in one way or another, with the edges of the academic process and the process of evaluation. Because it is there, at these edges, in the processes of agents' real socialisation and in the processes of the corporate organisation of the centres, where we can understand the individual processing of the subjects. This is how we reconstruct the path that goes from relational sensitivities to individualist codification, in order to try to answer the following question, which I consider to be fundamental: How is the individual culturally thinkable? What is the individual's social form (cf. Morris 1991)?

\section{The school as a universalist and instrumentalist device}

Let us briefly return to northern Norway, in order to formulate another question with important consequences: To what point can the school institution place its universalist pretension at the service of the subjects' local, and therefore real, ${ }^{5}$ life? To what point can it be a locally relevant institution (Barnhardt 2002)?

The Norwegian Constitution has, since 1988, imposed upon the state government the responsibility of guaranteeing a legal framework so that the 'Saami population group can safeguard and develop its language, culture, and social life'. ${ }^{6}$ The introduction of this clause into the Constitution was the result of a long process of ethno-political acknowledgement that bore its first institutional fruit in the 1980s. The role of the school and school agents in this ethno-political development is unquestionable, as is the school's ambiguous historical position, first as a means of colonisation and assimilation and later as a means of acknowledgement and management of ethnic diversity in Norway. One of the crucial moments of school protagonism in this process occurred in 1997, with the preparation of a curriculum to be specifically applied to the schools of six municipalities, with the so-called 'Administrative District for the Saami Language' included. ${ }^{7}$ The document, known by the abbreviation O97S, consists of an ambitious study plan for primary schools that pays attention to a number of areas of knowledge that are considered to be basic for developing a new school concept: the so-called 'Saami school'. Jan Henry Keskitalo has drawn attention to the curriculum project's aspiration to create a school with eminently local profiles, when quoting the official text:

Teaching should have a content and quality that provide basic competences, that favor the vitality of cultural tradition, that motivate taking local culture into consideration, and that confer upon children and youth the inclination to participate actively and creatively in Saami society and in Norwegian society. (Gonagaslaš girko-, oabpabus- ja dutkandepartementa 1997: 57, quoted in Keskitalo 2003: 23)

5 'Real' here means: close to the subjects' lived experience, belonging to the sphere of their life world (cf. Schutz and Luckmann 1977; Díaz de Rada and Cruces 1994; Díaz de Rada 2004).

6 Constitution of the Kingdom of Norway (Kongeriket Norges Grundlov $\$ 110$ a).

7 In paragraph 3-1.1, Saami Law (Justisdepartementet 1987) establishes this District (Forvaltningsomradet for Samisk Språk) in which the municipalities of Karasjok, Kautokeino, Nesseby, Porsanger, Tana and Kåfjord are included. Kautokeino is the Norwegian name for Guovdageaidnu. 
Reality, however, leaves much to be desired. Two books published in 2003 evaluate the success of the curriculum plan promoted by the 1997 reform (Hirvonen 2003a, $2003 \mathrm{~b}$ ). These books highlight the idea that the limitations that the universalist school has for processing a locally relevant education are found in the very form of institutional school logic. Jan Henry Keskitalo indicates how the teaching programmed with municipal and district accents have given up space to projects oriented towards and financed by the state (Keskitalo 2003: 32).

A fundamental aspect of these limitations can be found at the very heart of the pedagogical reasoning of the educational workers at the Saami University School of Guovdageaidnu (Sámi Allaskuvla), who work to defend their cultural rights. This is where the limits of the notion of 'local' reveal themselves most clearly, when the school mediates them. For the school as well as for the state, the notion of 'local' offers a restricted spectrum of meanings. 'Local' can mean, in a merely administrative sense, 'municipal', but generally, and most especially when cultural diversity is conceived in ethnic terms, 'local' means 'ethno-national' and, in this northern Norwegian context, 'indigenous'. These rhetorical detours are not insignificant because they reveal that the school, as a universalist institution, seems only to be capable of imagining subjects who are, in turn, universal, abstract, too general (Anderson 1993): 'Norwegians', 'Saami', 'Spaniards', 'Catalans', 'Westerners', 'indigenous peoples'. Thus, Jan Henry Keskitalo, interested in the 'development of the 'Saami School' and its local adaptation', criticises the fact that the best plans put into action since 1997 'do not, however, guarantee a Saami content, but rather local contents’ (Keskitalo 2003: 33).

The critical effort made by Keskitalo among other authors implies a decided push towards localisation, in the interplay of relations between centres and peripheries. Insofar as he is dealing with defending and promoting the basic rights of peripheral, colonised populations, it is reasonable for what is 'Saami' to be opposed to what is 'Norwegian', just as what is local in a specific herding district, or in a specific group of cognatic kin, is opposed in Guovdageaidnu to what is local-municipal (cf. Skålnes 2003). But what I hold here is that the universalist school seems unable to go beyond the ethnic horizon of what is local and, because of this, is incapable of responding, as Mikkel Nils Sara suggests in the same critical context, to the varied local meanings of what is local, that is, to what is local as it is experienced by flesh and blood subjects:

In the Saami situation the word local [ báikkálaś] refers to near experience [...]. But in these new times, other groups have arisen, for whom what is local is the same as a municipality, or a central town and the nearby district where people coexist in their free time. Consequently, with reference to the students [at the school], there are enormous differences in what is, for them, local; in this situation, the easiest solution may be to create a way of teaching that responds to an apparently homogeneous understanding of what is local. (Sara 2003: 133)

In Los primeros de la clase y los últimos románticos, I developed a comprehensive outline of what I considered at that time to be the basis of this universalist impulse: the instrumental vision of teaching (Díaz de Rada 1996: 13ff.); a vision that idealises school as an abstract device for transmitting de-localised knowledge. A brief list of some of the principles of this instrumental vision of teaching is the best way to point out the profiles of the bureaucratic production of reality in the school and to indicate some general strategies for doing ethnography in schools. 
1. In opposition to the principle of functional equivalence, ${ }^{8}$ ethnography should illustrate that agents are not interchangeable. This is why it is necessary to pay attention to the real trajectories, forms of action and biographies of those who occupy the positions in a school.

2. Equality, equalisation, discipline. The institution tends to reduce the subjects to their functions in an ideal chart, offering a disciplinary regime that shows two sides: the nice side of democratic equality and the not-so-nice side of bureaucratic equalisation. As opposed to this vision, ethnography should pay attention to the constant conflict between rights and duties in school institutions, seeking the empirical segmentations and compromises that are enacted across the segments of the ideal chart.

3. Under the instrumental vision of teaching, school agents tend to understand institutional ends as instrumental, technical needs, not negotiated, conventional, political purposes. But ethnography cannot, on any account, work under the assumption that school education is naturally indispensable and inevitable. Ethnographers must consider, at each step, that the school is only one among many possibilities of practising education, and they must concern themselves with illustrating this comparatively, using anthropology and history.

4. Normalisation as a specifically scholastic way of acknowledging diversity. Ethnography must understand normalisation as an ideal aspiration, which should constantly be contrasted with effective practice. By legitimating the unequal distribution of credentials, the school is working under the ideological assumption that it applies the same standards of normalisation, and, consequently, the same standards of difference, to all subjects. But this is not the case. The concept of statistical deviation, for example, which homogenises the subjects' differences as arithmetic distances from an average, is not the only operative concept of 'difference' that we find in all school centres. The meaning of this word is negotiated in different ways in different schools and multiple expressions that compete for legitimacy are found even within each (cf. Díaz de Rada 1996). Because of this, ethnography must document not only the real differences in empirical educational processes, but also the different ways of understanding difference itself and of negotiating difference (cf. Baumann and Gingrich 2004).

5. The utilitarian idea that education is a means that subjects use to fulfil rationally defined and universally acknowledged ends. Pedagogy, just like any other expert system of knowledge in the area of all the sciences (but even more so because the school is theoretically located at the productive centre of science itself), idealises its own practices in the context of a set of universalist educational theories. These theories try to shape the curriculum, including pedagogical strategies that systematically pretend that they are free from local contexts: elaborated codes, vertical forms of knowledge (Bernstein 1974, 1986, 1999). Ethnography, collaborating with the pedagogical discourses that are conscious of these idealisations (Giroux and Flecha 1992; Pérez Gómez 1998), should reveal the tensions between this de-localising aspiration and the principle of cultural relevance. Human institutions are not instruments that we use, like tools that are external to our bodies, but rather sets of rules that construct us inside and shape the way we relate to others.

8 This is a general principle of bureaucratic organisation that makes the concrete agents interchangeable: it doesn't really matter too much who does the task, all that matters is that the task get done (Parsons 1966; Wallace 1972). 
But none of this is feasible if we do not first understand that this instrumental vision of teaching is, in itself, a potent paradigm that produces evidence. As a result of this instrumental vision, the primary order of school reality is one of two supposedly coordinated devices: the processes of teaching and learning, and the processes of scholastic evaluation. So potent is this construction of reality that a good part of our own history as anthropologists of education and ethnographers of the school has been erected upon the obsession for understanding the so-called 'transmission and acquisition of culture' (Gearing 1979; Spindler 1987; Wolcott 1991; García Castaño and Pulido 1994). It is as if the entire educational process, in any location, could be subsumed under the eminently scholastic point of view of a cultural content that passes from mind to mind, intangible and untouched by the minds and bodies among which it moves. In an article titled 'La cultura como objeto', Honorio Velasco and I criticised this idea (Díaz de Rada and Velasco 1996; Ogbu 1981). The school curriculum and this version of 'culture', as instrumental reifications of knowledge, can and should be considered in continuity with any other form of positivist reification (Apple 1986; London 2002).

We thus have to partly overcome our own anthropological history in order to do ethnography in the school. And this is because we anthropologists have also had to go to school, and we have learned the school's particular and effective way of restricting the field of culture.

\section{The school as a device to restrict the cultural field}

One of the school's many missions is to define what should be considered 'culture', that is, legitimate culture (Bourdieu 1989). And when it defines culture, it must demarcate it and objectify it. One of the missions of social and cultural anthropology, and ethnography along with it, is to interpret any form of social life for the purpose of comparison, and it uses the concept of 'culture' for this, too. Sometimes, as I pointed out, the concept of culture that we ethnographers use is close to the restricted and objectified concept that the school uses, and then we are doing bad ethnography. Sometimes we understand the concept of culture as a theoretical category that allows us to reflect, without restrictions, on everything that human beings do and might do using communication. When we work like this, we understand culture to be a reflexive and local process, a set of conventions put into action. The subjects, theoretically, are made up of these conventions when they put them into action; and when they put them into action, they are their agents and can negotiate them to the point of modifying them. This idea of local culture as reflexive culture implies that concrete social subjects are inseparable from their concrete, open codes of communication. As opposed to this, the school proposes an idea of culture as transitive culture, defining it as an object that is external to the subjects and that they, whoever they may be, can appropriate. This transitive idea of culture requires us to understand culture as something with edges, something approachable, apprehensible, limited; it must be possible to trap, incorporate, internalise culture, as an object which is clear cut, with no reference to concrete social body. This restriction of the cultural field is the third axis of the school institution's production of evidence, which we have to be careful of when we are producing our own data. 
It is true that, as schooled social scientists, we waver in anguish between the extremes of these definitions of culture. Following Bourdieu, we can speak, for example, of a 'cultural capital' (Bourdieu 1988), when what we should say is simply 'school (objectified) capital' (Grignon and Passeron 1982); but if we say 'school capital', will we not be ignoring that, once it has been touched by the labour of demarcation and objectification that the school carries out, culture, any form of culture, can no longer be what it was before?

Let us travel once again to northern Europe to illustrate this last matter. In Sápmi, the Saami name for this territory without frontiers that is today distributed among four states, and colonised historically by Russia, Denmark/Norway, Sweden and Finland, there were no schools before colonisation. The implantation of schools, as religious agents of the respective states, began in the 18th century; but the school began to stand out as a political instrument at the beginning of the 20th century (Solbakk 1997: $144 \mathrm{ff}$.; Guovdageainnu Historjasearvi 2002, 2003).

Those who spent their childhood working in reindeer herding, in particular, conceive of the school as an institution that has usurped space and time in social life. Some of these people, like Karen Marie Eira Buljo, who coordinates a network of women who work in reindeer herding, do not believe at all that school is the best way to educate the young people who will go into that line of work and they seek to promote a partial withdrawal of the school from their children's lives, with significant local recognition (Boazodoallohálddahus 2001: 75 ff.). In general, though, I think that few of the people there doubt that the school, with all of its ambivalence, has, in the long run, played an irreplaceable role in defending and restoring the dignity of the colonised people in the eyes of the colonisers. Just as few would cast doubt on the school being a crucial institution for maintaining language diversity and the acknowledgement of local knowledge. Whether they have a blind faith in the school's capacity to produce accredited social distinction is another matter altogether. Especially when dealing with the world of the reindeer, I have been able to see how respected those who work in this activity, which for us is manual, are in Guovdageaidnu. I have also been able to hear colleagues at the Saami University School and the Saami Institute, professors and researchers like myself, speak reverently about the forms of knowledge and the ways of doing things of their relatives who work with the reindeer; I heard one of them express how proud he was that his son was planning on going into this activity in the future. And all of this despite the fact that it was then just two years ago that a system of formal credentials for doing this work was beginning to be designed. This system was explained by Inger Anita Smuk, the director of a new institution called the Office for Teaching Reindeer Work (Boazodoallu Oahpabus Kantwvra) at the first Conference of the Young People of the Reindeer, celebrated in Guovdageaidnu on 13 February 2004. The system has been designed with the hope of professionally accrediting a kind of knowledge that has never been based on accreditation. ${ }^{9}$ The basic intention is to legally enable people to continue with university studies, in an economic activity that has acute problems of sustainability. The doubt that was formulated earlier is expressed empirically here: will the reindeer workers, in relation to the local population, be able to

9 The Institute of secondary education in Guovdageaidnu offers professional training associated with the reindeer business. The real validity of this learning is constantly questioned. Besides, this training has shown itself to be insufficient to encourage the youth who work with the reindeer to continue their schooling. 
maintain their indifference to the legitimation principles of the new credential system? Will this new accreditation system, if it prospers, introduce a principle of stratification based on qualifications? As of today, as far as reindeer work is concerned, there is no such stratification. People simply do not believe that the school can determine what the 'reindeer culture' is and, consequently, they don't believe, either, that this supposed 'culture' can be isolated and demarcated from the social agents who, in fact, put it into practice on a daily basis.

\section{The communicative function of ethnography}

The different ways that the school and ethnography produce reality also considerably limit the capacity of ethnographers and those who make the school from within (educators, education scientists, technicians, politicians, etc.) to understand one another. In my opinion, the key to these clashes is rooted in the concept of culture and its social uses. Annette Weiner has formulated this idea with great precision: 'anthropology no longer can claim proprietary rights to a concept that is already part of many other fields and interests' (Weiner 1995: 18).

What we can do is to communicate the advantages of a concept of culture oriented towards an analytic comprehension of any form of social life, with no restrictions. In order to achieve this, we need to understand culture as a non-restricted set of conventions, constructed by social agents in their practical lives and reconstructed theoretically by ethnographers in their specialised activity. Our task is to communicate, in a responsible way, why this concept of culture is better than others, and what it is better for. We should also make an effort to clarify the disadvantages of other concepts of culture which, in one way or another, have fed on the knowledge provided by social and cultural anthropology: among others, culture as the excuse for legitimising static visions of the social process, substances contained within frontiers, frozen populations (cf. Rapport 2003), culture as a weapon of 'cultural fundamentalism' (Stolcke 1995) and as a euphemism of the notion of race (Kuper 2001); or culture as merchandise (Weiner 1995).

The concept of culture that I am proposing here involves a theoretical minimum: all concrete human beings live their social life in some relatively coherent framework of intersubjective conventions, a framework which is complex in the sense that it is made up of a set of related institutions. ${ }^{10}$ This idea allows us to understand the conventional, that is, the contingent, historical and concrete, character of culture, as

10 There are two minimum requirements for this concept of culture: on one hand, the notion of 'way of social life', which goes back to Herder (Caisson 1991) and was analytically developed by the Boasian tradition; on the other hand, the notion of institutional organisation, to which Malinowski gave birth (1984). When we warn about the relative coherence of this set of conventions that makes up culture, we are warning against the exaggeration of cultural coherence by certain traditional definitions of the concept, based especially on the metaphors of culture and language (see, for example, Goodenough 1981). Keesing's (1982) critique of the concept of 'cultural rule' shows that this exaggerated coherence also tends towards cultural substantialism and an excessively insular vision of culture. For other critiques, see our discussion of the problems involved in the analytic language of practice (Díaz de Rada and Cruces 1994), Barth's naturalistic proposal for the examination of the 'open systems of disorder' (particularly, Barth (1992), cf. Barth (1993)), and Baumann's comprehension of culture as discourse (Baumann 1999). 
opposed to the supposedly universal and technically necessary character of school knowledge. In addition, it prepares us to see human life in the complex set of institutional relations, as opposed to the bureaucratic fragmentation of social life in specialised institutions that operate under an ideological assumption of relative autonomy (school education, economy, politics, etc.). Finally, this idea invites us to keep in mind the practical and active nature of the concept of culture as a 'way of life', as opposed to the techno-instrumental dissociation of school knowledge into theoretical knowledge (that represents the world) and practical knowledge (that operates upon the world).

We should convincingly defend this concept of culture, and prove that it serves an analytic interest better than any other. If we seek reforms based on knowledge, then any one of the variants of the anthropological concept of culture that I have summarised is simply superior, that is, optimally useful.

\section{Ángel Díaz de Rada}

Universidad Nacional de Educación a Distancia (Spain)

Department of Social and Cultural Anthropology,

cl Senda del Rey, 7, 28040 Madrid, Spain

tuescribeme@hotmail.com

\section{References}

Anderson, Benedict. 1993 [1983]. Comunidades imaginadas. Reflexiones sobre el origen y la difusión del nacionalismo. Mexico: Fondo de Cultura Económica.

Apple, Michael W. 1986 [1979]. Ideología y currículo. Madrid: Akal.

Asad, Talal. 1993. Genealogies of religion: discipline and reasons of power in Christianity and Islam. Baltimore: The John Hopkins University Press.

Barnhardt, Ray. 2002. 'Domestication of the ivory tower: institutional adaptation to cultural distance', Anthropology and Education Quarterly 33(2): 238-49.

Barth, Fredrik. 1992. 'Towards greater naturalism in conceptualizing societies', in Adam Kuper (ed.), Conceptualizing society. 17-33. London: Routledge.

Barth, Fredrik. 1993. 'Are values real? The enigma of naturalism in the anthropological imputation of values', in Michael Hechter, Lynn Nadel and Richard E. Michod (eds.), The origin of values, 27-46. New York: Aldine de Gruyter.

Baumann, Gerd. 1999. The multicultural riddle. New York: Routledge.

Baumann, Gerd and Andre Gingrich. 2004. Grammars of identity/alterity. A structural approach. New York: Berghahn.

Bernstein, Basil. 1974. Class, codes and control (3 vols.). London: Routledge and Kegan Paul.

Bernstein, Basil. 1986. 'On pedagogic discourse', in J. G. Richardson (ed.), Handbook of theory and research for the sociology of education. New York: Greenwood Press.

Bernstein, Basil. 1999. 'Vertical and horizontal discourse: an essay', British Journal of Sociology of Education 20(2): 158-73.

Boazodoallohálddahus. 2001. Report from the seminar Nissonolbmot ja boazodoallu/Kvinner og reindrift. Alta: Reindriftsforvaltningen Øst-Finnmark.

Bourdieu, Pierre. 1988 [1979]. La distinción. Madrid: Taurus.

Bourdieu, Pierre. 1989. La noblesse d'etat. Paris: Minuit.

Caisson, Max. 1991. 'Lumière de Herder', Terrain 17: 17-28. Special edition entitled En Europe, les nations.

Cruces, Francisco, Ángel Díaz de Rada, Honorio Velasco, Roberto Fernández, Celeste Jiménez de Madariaga and Raúl Sánchez Molina. 2002. 'Trust, cosmetics or suspicion? A multi-sited ethnography of the relationships between users and institutions in six Spanish expert systems', Focaal. European Journal of Anthropology 40: 35-49. 
Díaz de Rada, Ángel. 1996. Los primeros de la clase y los últimos románticos. Una etnografía para la crítica de la visión instrumental de la enseñanza. Madrid: Siglo XXI.

Díaz de Rada, Ángel. 2003. 'Las formas del holismo. La construcción teórica de la totalidad en etnografía', Revista de dialectología y tradiciones populares LVIII(1): 237-62.

Díaz de Rada, Ángel. 2004. 'El sujeto en la corriente. Reflexiones sobre el sujeto social en condiciones de globalización', in Luis Díaz Viana (ed.), El nuevo orden del caos: consecuencias socioculturales de la globalización. Madrid: CSIC.

Díaz de Rada, Ángel and Francisco Cruces. 1994. 'The mysteries of incarnation: some problems to do with the analytic language of practice', in Kirsten Hastrup and Peter Hervik (eds.), Social Experience and Anthropological Knowledge, 101-20. London: Routledge.

Díaz de Rada, Ángel, and Honorio Velasco. 1996. 'La cultura como objeto', Signos 17: 6-12.

Dreeben, Robert. 1968. On what is learned in school. Menlo Park: Addison-Wesley.

Dumont, Louis. 1987 [1983]. Ensayos sobre el individualismo. Madrid: Alianza.

Eddy, Elizabeth M. 1975. Becoming a teacher. The passage to professional status. New York: Teacher College Press.

Erickson, Frederick and Kris Gutierrez. 2002. 'Culture, rigor, and science in educational research', Educational Researcher 31(8).

Everhart, Robert B. 1983. Reading, writing and resistance. Adolescence and labor in a junior high school. London: Routledge and Kegan Paul.

Feuer, Michael J., Lisa Towne and Richard J. Shavelson. 2002. 'Scientific culture and educational research', Educational Researcher 31(8).

García Castaño, Javier and Rafael A. Pulido. 1994. Antropología de la educación. El estudio de la transmisión-adquisición de cultura. Madrid: Eudema.

Gearing, Frederick. 1979. 'A reference model for a culture theory of education and schooling', in Frederick Gearing and L. Sangree, Toward a cultural theory of education and schooling. New York: Mouton.

Giddens, Anthony. 1984. The constitution of society. Outline of the theory of structuration. Oxford: Polity Press.

Giddens, Anthony. 1987 [1967]. Las nuevas reglas del método sociológico. Crítica positiva de las sociologias interpretativas. Buenos Aires: Amorrortu.

Giddens, Anthony. 1990. The consequences of modernity. Cambridge: Polity Press.

Giroux, Henry A. and Ramón Flecha. 1992. Igualdad educativa y diferencia cultural. Barcelona: El Roure.

Gonagaslaš girko-, oahpahus- ja dutkandepartementa. 1997. 10-jagi vuođđđoskwvlla sámi oahppoplánat. Oslo.

Goodenough, Ward H. 1981. Culture, language, and society. Menlo Park: Benjamin/Cummings.

Grignon, Claude, and Jean-Claude Passeron. 1982. Sociologie de la culture et sociologie des cultures populaires. Paris: Gides.

Guovdageainnu Historjasearvi. 2002, 2003. Govvagirji IV and Govvagirji VI, Volumes 8 and 10, respectively, in the series Muitalusat ja dáhpáhusat Guovdageainnus. Alta: Fagtrykk Alta.

Habermas, Jürgen. 1984 [1968]. Ciencia y técnica como 'ideología'. Madrid: Tecnos.

Habermas, Jürgen. 1988. 'Discusión con Niklas Luhmann (1971): ¿teoría sistémica de la sociedad o teoría crítica de la sociedad?’ In La lógica de las ciencias sociales, 310-49. Madrid: Tecnos.

Hansen, Judith Friedman. 1979. Sociocultural perspectives on buman learning. Foundations of educational anthropology. Prospect Heights: Waveland Press.

Harris, Grace Gredys. 1989. 'Concepts of individual, self, and person in description and analysis', American Anthropologist 91: 599-612.

Herzfeld, Michael. 1992. The social production of indifference. Exploring the symbolic roots of Western bureaucracy. London: The University of Chicago Press.

Hirvonen, Vuokko. 2003a. Mo sámáidahttit skuvlla? Reforpma 97 evalueren. Kárášjohka: Cálliidlágádus.

Hirvonen, Vuokko (ed.) 2003b. Sámi skuvla plánain ja praktibkas. Mo dustet O97S hástalusaid? Reforpma 97 evalueren. Kárášjohka: Čálliidlágádus. 
Joks, Solveig. 2001. 'Boazosámi nissonolbmot. Guovddážis báike- ja siidadoalus muhto vajálduvvon almmolaččat', Dieđut 2001, 5.

Justisdepartementet. 1987. Law 1987-06-12 Num. 56, Lov om sametinget og andre samiske rettsforbold (sameloven).

Kalstad, Johan Klemet Hætta. 1999. 'Reindriftspolitikk og samisk kultur - en uløselig konflikt? En studie av reindriftstilpasninger og moderne reindriftspolitikk', Dieđut 1999, 2.

Keesing, Roger M. 1982. 'Cultural rules. Methodological doubts and epistemological paradoxes', Camberra Anthropology 5(1).

Keskitalo, Alf Isak. 1998. Guovdageainnu suobkangirji/Kautokeino sognebok. Kautokeino: Kautokeino kommune.

Keskitalo, Jan Henry. 2003. 'Sámi skuvlla' ovdáneapmi ja dan báikkálaš heiveheapmi - suohkaniid ja skuvllaid plánáin ja oahpaheddjiid oaiviliid mielde', in Vuokko Hirvonen (ed.), Sámi skuvla plánain ja praktibkas. Mo dustet O97S hástalusaid? Reforpma 97 evalueren, 20-35. Kárášjohka: Cálliidlágádus.

Kuper, Adam. 2001. Cultura. La versión de los antropólogos. Barcelona: Paidós.

Landbruksdepartementet. 1978. Law 1978-06-09 Num. 49: Lov om reindrift.

Lareau, Annette and Wesley Shumar. 1996. 'The problem of individualism in family-school policies', Sociology of Education 69: 24-39.

Lave, Jean. 1989. Cognition in practice. Mind, mathematics, and culture in everyday life. New York: Cambridge University Press.

Lerena, Carlos. 1983. Reprimir y liberar. Crítica sociológica de la educación y de la cultura contemporáneas. Madrid: Akal.

London, Norrel A. 2002. 'Curriculum convergence: an ethno-historical investigation into schooling in Trinidad and Tobago', Comparative Education 38(1): 53-72.

Malinowski, Bronislaw. 1984 [1944]. Una teoria científica de la cultura. Madrid: Sarpe.

Mayntz, Renate. 1985. Sociología de la administración pública. Madrid: Alianza.

Mayntz, Renate. 1987. Sociología de la organización. Madrid: Alianza.

Morris, Brian. 1991. Western conceptions of the individual. Oxford: Berg.

Ogbu, John U. 1981. 'School ethnography: a multilevel approach', Anthropology and Education Quarterly XII(1): 3-29.

Paine, Robert. 1994. Herds of the tundra. A portrait of Saami reindeer pastoralism. London: Smithsonian Institution Press.

Paine, Robert. 2004. 'Saami reindeer pastoralism: Quo vadis?', Ethnos 69(1): 23-42.

Parsons, Talcott. 1966. Estructura y proceso en las sociedades modernas. Madrid: Instituto de Estudios Políticos.

Pérez Gómez, Ángel I. 1998. La cultura escolar en la sociedad neoliberal. Madrid: Morata.

Rapport, Nigel. 2003. "Culture is no excuse". Critiquing multicultural essentialism and identifying the anthropological concrete', Social Anthropology 11(3): 373-84.

Ricoeur, Paul. 1990. Soi-même comme un autre. Paris: Seuil.

Sara, Mikkel Nils. 2003. 'Árbevirolaš sámi dieđut ja máhtut sámi vuođđoskuvllas', in Vuokko Hirvonen (ed.), Sámi skuvla plánain ja praktibkas. Mo dustet O97S hástalusaid? Reforpma 97 evalueren, 12138. Kárášjohka: Čálliidlágádus.

Schutz, Alfred and Thomas Luckmann. 1977 [1973]. Las estructuras del mundo de la vida. Buenos Aires: Amorrortu.

Shulman, Lee S. 2002. 'Truth and consequences? Inquiry and policy in research on teacher education', Journal of Teacher Education 53: 248-53.

Skålnes, Sunniva. 2003. Bustad og beiteland. Noregs teknisk-naturvitskaplege universitet: Fakultet for arkitektur og bilekunst. Dr. Ingeniøravhandling 2003:51.

Solbakk, Aage. 1997. Sami historjá 2. 1751 rájes dálá áigái. Kárášjohka: Davvi girji.

Spindler, George D. 1987. 'The transmission of culture', in George D. Spindler (ed.), Education and cultural process. Anthropological approaches, 303-34. Prospect Heights, IL: Waveland Press.

Steen, Adolf. 1956. 'Flytninger og byer', in Kautokeinostudier, 74-112. Oslo: Norsk Folkemuseum.

Stolcke, Verena. 1995. 'Talking culture. New boundaries, new rhetorics of exclusion in Europe', Current Anthropology 36(1): 1-24. 
Varenne, Hervé. 1982. 'Jocks and freaks: the symbolic structure of the expression of social interaction among American senior school students', in George Spindler (ed.), Doing ethnography of schooling. Educational anthropology in action, 210-35. New York: Holt, Rinehart \& Winston.

Velasco, Honorio and Ángel Díaz de Rada. 1997. La lógica de la investigación etnográfica. Un modelo de trabajo para etnógrafos de la escuela. Madrid: Trotta.

Velasco, Honorio, Ángel Díaz de Rada, Francisco Cruces, Roberto Fernández, Celeste Jiménez de Madariaga and Rául Sánchez. 2006. La sonrisa de la institución. Confianza y riesgo en sistemas expertos. Madrid: Editorial Universitaria Ramón Areces.

Wallace, Anthony F. C. 1972. Cultura y personalidad. Buenos Aires: Paidós.

Weber, Max. 1984 [1922]. Economía y sociedad. Esbozo de sociología comprensiva. Mexico: Fondo de cultura económica.

Weiner, Annette B. 1995. 'Culture and our discontents', American Antbropologist 97(1): 14-21.

Willis, Paul. 1978. Learning to labour. How working class kids get working class jobs. London: Saxon House.

Willis, Paul. 1981. 'Cultural production is different from cultural reproduction is different from social reproduction is different from reproduction', Interchange 12(2-3): 48-67.

Wolcott, Harry F. 1985. 'On ethnographic intent', Educational Administration Quarterly XXI(3): 187203.

Wolcott, Harry F. 1990. Writing up qualitative research. London: Sage Publications.

Wolcott, Harry F. 1991. 'Propriospect and the acquisition of culture', Antbropology and Education Quarterly 22(3): 251-73.

Wolcott, Harry F. 1999. Ethnography. A way of seeing. London: Sage, Altamira.

\section{Abstracts}

\section{Bureaucratie Scolaire, Ethnographie et Culture: Obstacles Conceptuels à l'Ethnographie dans les Ecoles}

L'objectif de cette contribution est d'offrir une réflexion sur les obstacles rencontrés dans le travail ethnographique dans les institutions scolaires. Ces obstacles sont présentés de façon conceptuelle par rapport aux trois axes principaux qui forment l'école en tant que réalité bureaucratique: l'école en tant que moyen hypertrophié de codification individuelle, l'école en tant que dispositif universaliste et instrumentaliste, et l'école en tant qu'instrument destiné à limiter le domaine culturel. Ces idées sont illustrées par des exemples empiriques dont la majorité proviennent de recherches en cours à Guovdageaidnu, dans le nord de la Norvège.

\section{Schulbürokratie, Ethnographie und Kultur: Konzeptionelle Hindernisse für Ethnographie in Schulen}

Es ist das Ziel dieses Artikels, eine Reflexion über Hindernisse anzubieten, die ethnographisches Vorhaben blockieren, wenn wir versuchen, Ethnographie in schulischen Institutionen durchzuführen. Diese Hindernisse werden konzeptuell dargestellt und auf drei Hauptachsen bezogen, die Schule als eine bürokratische Realität formen: Schule als ein hypertrophiertes Mittel individualistischen Kodierens, Schule als universalistischer und instrumentalistischer Apparat, und Schule als ein Instrument zur Begrenzung des kulturellen Felds. Diese Ideen werden durch einige empirische Beispiele illustriert, in der Mehrzahl stammen diese aus einer laufenden Forschung in Guovdageaidnu, Nordnorwegen. 
Burocracia Escolar y Etnografía: Obstáculos Conceptuales para Hacer Etnografía en las Escuelas

El objetivo de este ensayo es el de ofrecer una reflexión sobre los obstáculos que frenan el propósito etnográfico cuando intentamos hacer etnografía en instituciones escolares. Estos obstáculos se presentan conceptualmente con referencia a tres ejes principales que forjan la escuela como una realidad burocrática: la escuela como un medio hiperatrofiado de codificación individualista, la escuela como un dispositivo universalista e instrumentalista, y la escuela como un dispositivo para restringir el campo cultural. Estas ideas son ilustradas mediante algunos ejemplos empíricos, de los cuales la mayoría provienen de una investigación en curso en Guovdageaidnu, en el norte de Noruega. 